\title{
Action of Trichodermil 1306 in the control of Fusarium oxysporum f. sp. lycopersici in tomato crops
}

\section{Ação do Trichodermil 1306 no controle de Fusarium oxysporum f. sp. Iycopersici na cultura do tomateiro}

\author{
Isis Bruna Portolan1,* (D) (https://orcid.org/0000-0003-4388-3512) \\ Silmara Rodrigues Pietrobelli ${ }^{1}$ (D) (https://orcid.org/0000-0003-3486-6622) \\ Gabriela Silva Moura' (D) (https://orcid.org/0000-0003-0404-2331) \\ Aline Pomari Fernandes ${ }^{1}$ (D) (https://orcid.org/0000-0001-7266-1914) \\ Lisandro Tomas da Silva Bonome ${ }^{1}$ (D) (https://orcid.org/0000-0002-4144-3014) \\ Gilmar Franzener ${ }^{1}$ (D) (https://orcid.org/0000-0002-3226-2270)
}

\begin{abstract}
Fusarium wilt, caused by Fusarium oxysporum f. sp. lycopersici, is one of the most important diseases of tomato crop in Brazil. Several alternatives to fungicides have been evaluated in search for products that control this disease and have low environmental impact and toxicity to living beings. In this context, the use of Trichoderma spp. is an alternative to agrochemicals, since they are bioregulators and antagonists of several phytopathogens. This work aimed to evaluate the antagonistic and mycoparasitory action of the Trichodermil 1306 biofungicide against $F$. oxysporum, and its action in the control of fusarium wilt in tomato seeds and seedlings. The biofungicide was used at concentrations of 0,50 , 100 , and $150 \%$ of the dose recommended for application of 20 $\mathrm{L}$ with a backpack sprayer. The experiment was conducted in a completely randomized design with five replications. Data were submitted to analysis of variance and mean compared by Tukey's test at $5 \%$ probability. The $100 \%$ Trichodermil concentration was the most efficient for treating tomato seeds. Although this concentration did not show differences in relation to the lowest dose used (50\%) in the tomato seed antagonism, mycoparasitism and $F$. oxysporum incidence tests were recommended because that the lowest concentration resulted in $18 \%$ lower root protrusion than that observed with $100 \%$ dosage. The in vitro antagonistic and mycoparasitory action of this biological fungicide indicates its potential in the control of fusarium wilt in tomato crops.
\end{abstract}

KEYWORDS: Trichoderma; antagonism; biofungicide; fusarium wilt.
RESUMO: A murcha-de-fusário, causada por Fusarium oxysporum f. sp. lycopersici, é uma das mais importantes doenças da cultura do tomate no Brasil. Várias alternativas aos fungicidas têm sido avaliadas na busca de produtos que controlem a doença e tenham baixo impacto ambiental e toxicidade aos seres vivos. Nesse contexto, o uso de Trichoderma spp. é uma alternativa a agrotóxicos, pois são biorreguladores e antagonistas de vários fitopatógenos. O objetivo do trabalho foi avaliar a ação antagonista e micoparasitória do biofungicida Trichodermil $1306 \mathrm{em} F$. oxysporum, e no controle da murcha-de-fusário em sementes e mudas de tomate. O biofungicida foi utilizado nas concentraçōes de $0,50,100$ e $150 \%$ da dose recomendada para aplicação com pulverizador costal de 20 L. O experimento foi conduzido em delineamento inteiramente casualizado, com cinco repetiçóes. Os dados foram submetidos à análise de variância e as médias foram comparadas pelo teste de Tukey a 5\% de probabilidade. A concentração de Trichodermil 100\% foi a mais eficaz para o tratamento de sementes de tomateiro. Embora essa concentração não tenha se diferenciado da menor dosagem utilizada (50\%) para os testes de antagonismo, micoparasitismo e incidência de F. oxysporum em mudas de tomate, sua recomendaçáo se justifica pelo fato da menor concentraçáo ter propiciado protrusão radicular $18 \%$ menor do que a observada na concentraçáo de $100 \%$. A ação antagonista e micoparasitória in vitro do fungicida biológico testado no presente estudo indica potencialidade de uso para o controle de murcha-de-fusário em tomateiro.

PALAVRAS-CHAVE: Trichoderma; antagonismo; biofungicida; murcha-de-fusário. 


\section{INTRODUCTION}

Tomato [Solanum lycopersicum L., synonyms Lycopersicon esculentum Mill. and Lycopersicon lycopersicum (L.) H. Karst.], originally from South America, is one of the most expressive crops in the world scenery (CARVALHO et al., 2014a). Despite its great national representativeness, its cultivation requires special care, since it is susceptible to several diseases (SOUZA et al., 2014).

Among these diseases, fusarium wilt outstands. It is caused by the fungus Fusarium oxysporum f. sp. lycopersici (FERRAZ et al., 2014), and appears as one of the most important fungal diseases in the tomato cultivation in Brazil. It can be found in almost all the tomato producing regions (CANTÚ et al., 2014). This disease might provoke up to $100 \%$ loss in the crop (MARTÍNEZ et al., 2014).

This pathogen affects the plant root system, regardless of wounds, progressing to the xylem until the whole plant is affected. It presents three physiological races with resistance structures that guarantee its survival in adverse environmental conditions and its viability in cultivation areas (CARRER FILHO et al., 2015).

The use of chemical fungicides is the most used method to control the fusarium wilt. However, they present low efficacy and are not economically viable, since their results are not satisfactory or long lasting (SOUZA et al., 2014). In addition, in the last few years, society in general have been more concerned with health and environment, indicating the need for changes in the current agricultural production system seeking higher sustainability in the sector.

Therefore, the agroecological production of vegetables, mainly tomato, has grown globally in the last couple of years, especially for the need to preserve both producers' and consumers' lives and at the same time reduce impacts to the environment (SOUZA et al., 2015).

The development of production agroecological systems as an alternative to the intensive use of agrochemicals, inorganic inputs and unsustainable practices face management difficulties as any other productive system, mainly, regarding the control of diseases (MELO; SERRA, 2019).

One of the alternatives to the chemical control in the tomato crop is the use of biological control, which presents advantages such as target specificity, reduction of workers' exposure to agrochemicals, absence of residues in the food produced, low risk of environmental pollution and of causing pathogen resistance (SOUZA et al., 2014).

Trichoderma is a fungus genus that can act in biological control, since it is an antagonistic agent to a wide variety of fungi, including the F. oxysporum f. sp. lycopersici, either through parasitism, antibiosis and/or competition. Also, this genus might favor the growth of several vegetable species (LI et al., 2015; CARVALHO et al., 2015a).
The Trichoderma spp. relation with vegetable species usually occur in the root zone, the place where the fungus colonizes the epidermis and cortex cells, thus triggering a series of metabolic alterations that lead to the signal transduction of plant defense response against several pathogens (ZHANG et al., 2016).

The Trichoderma spp. antagonistic activity occurs through the production of volatile and nonvolatile metabolites such as the harzianic acid and alamethicin, in addition to the activity of lytic enzymes such as chitinases, glucanases and proteases (BRITO et al., 2014). The parasitism relation with phytopathogenic fungi might involve several events such as location, recognition, direct contact, formation of structures with the following functions: appressoria, penetration, knotting and development of parallel hypha, which might be observed using scanning electron microscopy (ZHANG et al., 2016).

Taking that into consideration, this study aimed to evaluate the in vitro antagonistic and mycoparasitory action of the biofungicide Trichodermil 1306 based on Trichoderma harzianum against $F$ oxysporum $\mathrm{f}$. sp. lycopersici and in the control of the fusarium wilt in tomato seeds and seedlings.

\section{MATERIAL AND METHODS}

The experiment was carried out in the greenhouse and Phytopathology, Vegetable Physiology and Germination and Growth Laboratories at the Federal University Fronteira Sul, Campus Laranjeiras do Sul, state of Paraná, Brazil.

The $F$. oxysporum $\mathrm{f}$. sp. lycopersici conidia were obtained from the fungi collection of the Phytopathology Laboratory. Next, 7-mm diameter fungi mycelial discs were placed on Petri dishes with potato dextrose-agar (PDA) solid culture medium and kept in Germination camera BOD type (biochemical oxygen demand) at $25^{\circ} \mathrm{C}$, in a dark environment for 7 days, for later use in the experiments.

The commercial biofungicide Trichodermil 1306 was used with active ingredient based on the T. harzianum fungi conidia, from the strain ESALQ 1306, as a concentrated solution. All tests were performed using the concentrations 0, 50, 100, and $150 \%$ of the dosage $0.25 \mathrm{~L}$ in $20 \mathrm{~L}$ water (recommended for application with the 20-L backpack sprayer).

\section{Test 1: Evaluation in vitro of the antagonism of the fungi $F$. oxysporum f. sp. Iycopersici by $\mathrm{T}$. harzianum in matched cultivation}

The antagonism of the $T$. harzianum based biological fungicide under $F$. oxysporum $\mathrm{f}$. sp. lycopersici was evaluated in a matching test, following an adaptation of the methodology 
proposed by SOLINO et al. (2017). First, 5-mm diameter fungi mycelial discs were placed on one end of the Petri dish and $40 \mu \mathrm{L}$ of Trichodermil was added on the other end. Next, the Petri dishes were kept in BOD for seven days at $25^{\circ} \mathrm{C}$ in dark environment. After that period, the mycelium growth was measured with a ruler, following a scale of scores proposed by BELL et al. (1982). The control was a PDA culture medium with the fungus mycelial discs on one end of the petri dish and $40 \mu \mathrm{L}$ sterile distilled water on the other end.

\section{Test 2: Antifungal activity in vitro of the biofungicide Trichodermil 1306 under $F$. oxysporum f. sp. lycopersici}

To evaluate the in vitro antifungal activity of the biofungicide under $F$. oxysporum f. sp. lycopersici, initially, 5-mm diameter discs containing fungus mycelium were placed on the center of each Petri dish. Next, $40 \mu \mathrm{L}$ of Trichodermil 1306 was applied on each disc. After that, the Petri dishes were kept in $\mathrm{BOD}$ at $25^{\circ} \mathrm{C}$ for 7 days. The control was a Petri dish containing the fungus disc on the PDA culture medium and $40 \mu \mathrm{L}$ sterile distilled water was applied on the disc. The evaluations were carried out on the 7 th day, by measuring the horizontal and vertical diameters of each colony with a ruler and determining the mean of the two values to infer the colony mean mycelial growth.

\section{Test 3: Effect of Trichodermil 1306 on the F. oxysporum incidence in seeds, root protrusion and initial development of tomato plantlets}

Tomato seeds from the cultivar Santa Cruz were immersed in a Trichodermil 1306 solution for $60 \mathrm{~min}$. Next, 25 seeds were placed in boxes of gerbox type on two sterilized filter paper sheets and wetted with distilled water, in the proportion of 2.5 times their weight. Before the seeds were placed in the box, they were immersed in a suspension of fungus spores at the concentration $1 \times 10^{5}$ conidia $\cdot \mathrm{mL}^{-1}$. The control contained seeds that were only immersed in sterile distilled water. Each box received a treatment and represented a replication. The boxes were kept at $25^{\circ} \mathrm{C}$, for 7 days in a 12-hour photoperiod. After that period, the tomato seeds that presented root protrusion were counted.

Simultaneously, the F. oxysporum f. sp. lycopersici incidence in the seeds and the symptomatology of the tomato plantlets that showed wilt were evaluated. The results were recorded as percentage of infected seeds per replication, root protrusion and seedling damping off.

\section{Test 4: Effect of Trichodermil 1306 on the F. oxysporum f. sp. lycopersici incidence in tomato seedlings}

To evaluate the efficiency of Trichodermil 1306 on the F. oxysporum $\mathrm{f}$. sp. lycopersici incidence in tomato seedlings, seeds of the cultivar Santa Cruz were soaked with the Trichodermil 1306 concentrations, for $60 \mathrm{~min}$. Next, they were sowed in a Plantmax germination substrate on a styrofoam tray, with one seed per whole. When they reached the first definite leaf, approximately 10 days after sowing, $0.5 \mathrm{~mL}$ pathogen conidia suspension was applied at a $1 \times 10^{5}$ conidia $\cdot \mathrm{mL}^{-1}$ concentration per irrigation on the substrate on each whole of the tray. The incidence of illnesses was determined in percentage, after weekly observations of the number of symptomatic seedlings (wilt, damping-off or necrosis) for 30 days. Each plot of 10 seedlings was considered a replication and the witness received distilled water. Based on the data obtained in the four evaluations, the area under the illness progress curve (AUIPC) was calculated using Eq. 1:

$$
\mathrm{AUIPC}=\Sigma[(Y i+Y i+1) \times 2-1 \times(T i+1-T i)](1)
$$

where AUIPC = area under the illness progress curve; $Y i=$ incidence at the time of evaluation and $T i=$ plant age at the time of the evaluation.

The tests were carried out in a completely randomized design with five replications. The statistical analysis of the results included normality and homogeneity tests. The results were submitted to the Tukey's test at $5 \%$ probability and regression whenever necessary. The computer program Sisvar was used for the analyses (FERREIRA, 2007).

\section{RESULTS AND DISCUSSION}

In the antagonism test, all the concentrations applied presented a $60 \%$ reduction in the development of $F$. oxysporum $\mathrm{f}$. sp. lycopersici, when compared to the control. In the mycoparasitism test, there was also a significant difference in the fungus mycelial growth with the concentrations 50,100 , and $150 \%$, with 69.6, 78.5, and $80.3 \%$ reduction, respectively. Both tests revealed that there was a satisfactory reduction in the pathogen growth with the $50 \%$ concentration when compared to the control (Table 1).

The results of the antagonistic effect and mycoparasitism tests demonstrated the efficiency of the biofungicide, which was seen to produce different results from those presented by the control. This might be explained by the fact that the genus Trichoderma is considered a natural biofungicide, which might reduce up to $100 \%$ the chances of any fungus to affect the crop, since it shows different 
Table 1. Mycelial growth mean values (cm) of $F$. oxysporum $\mathrm{f}$. $\mathrm{sp}$. lycopersici (mycoparasitism) and classification regarding antagonism submitted to Trichodermil 1306 different concentrations.

\begin{tabular}{lcc} 
Treatments & $\begin{array}{c}\text { Colony mycelial } \\
\text { growth }(\mathrm{cm})\end{array}$ & $\begin{array}{c}\text { T. harzianum } \\
\text { antagonism } \\
\text { classification }\end{array}$ \\
\cline { 2 - 3 } & Mycoparasitism & Antagonism \\
\hline Control & $5.6 \pm 0.90 \mathrm{~b}$ & $5.0 \pm \mathrm{Ob}$ \\
\hline Trichodermil 50\% & $1.70 \pm 0.66 \mathrm{a}$ & $2.0 \pm \mathrm{Oa}$ \\
\hline Trichodermil 100\% & $1.20 \pm 0.52 \mathrm{a}$ & $2.0 \pm 0 \mathrm{Oa}$ \\
\hline Trichodermil 150\% & $1.10 \pm 0.47 \mathrm{a}$ & $2.0 \pm 0 \mathrm{Oa}$ \\
\hline C.V. (\%) & 23.52 & 23.13 \\
\hline
\end{tabular}

*Means \pm EPM followed by the same letter in the column did not differ one from another in the Tukey's test at 5\% probability. Notes: 1) T. harzianum growth on the pathogen occupying the whole surface of the medium; 2) T. harzianum growth occupying over $2 / 3$ of the mean surface; 3) T. harzianum growth occupying half of the medium surface; 4) T. harzianum growth occupying $1 / 3$ of the medium surface and, 5) absence of $T$. harzianum growth.

mechanisms, through which it acts, among them the microbial competition outstands for acting as a root colonizer and not letting an ecological niche to other phytopathogenic fungi (TRIANA et al., 2017).

Many Trichoderma species are able to produce a series of secondary metabolites, both volatile and nonvolatile, which present a wide spectrum of antimicrobial action (CARVALHO et al., 2015b). In addition, there are studies showing the involvement of strains of these fungus species in the activation of plant defense mechanisms, as well as in the regulation of vegetable growth (ISAIAS et al., 2014).

The mycoparasitory process is complex and might involve the chemotrophic growth of Trichoderma towards the host stimulated by molecules such as amino acids and sugars, lectin-mediated recognition (SILVA et al., 2017), formation of hooks or appressorium like structures that contain high concentrations of osmotically active solutes such as glycerol, which facilitates penetration, extracellular hydrolytic enzyme secretion, and, finally, host penetration and death (TRIANA et al., 2017). Such metabolites are released in the fungus growth and sporulation phases and are some of the main natural products used to inhibit the growth of microorganisms (ISAIAS et al., 2014). By producing such metabolites, Trichoderma spp. manage to inhibit spore germination and phytopathogenic fungus hyphal stretching (TRIANA et al., 2017).

Fungi from the genus Trichoderma, in addition to acting as biocontrollers and enhancers of vegetable growth, also present rhizosphere competence (SILVA et al., 2015) when they are close to the plant roots. They can be used in formulas of soil biopesticides, biofertilizers and inoculants (CARVALHO et al., 2014b). Other relevant factors of this fungus genus are its action in biological control and its ability to produce compounds with similar activities to those of the vegetable hormones (BORTOLIN et al., 2019).

Currently, the chemical products used to control fusarium wilt result in a series of damage such as the contamination of the environment, risks to the human health and the appearance of pathogen resistant strains (FERREIRA et al., 2015). According to the antagonism and mycoparasitism test results (Table 1), the use of Trichodermil 1306 might be an alternative measure to the pathogen management, aiming mainly at restoring biodiversity.

The data obtained regarding the Trichodermil 1306 effect on the $F$. oxysporum f. sp. lycopersici incidence, the seed root protrusion and the initial development of tomato plantlets showed that the treated tomato seeds differed statistically from the control (Table 2). The lower pathogen incidence in the seeds was evidenced in the $150 \%$ concentration, with a $77 \%$ reduction when compared to the control. The concentrations 50 and $100 \%$ of the biofungicide resulted in 51 and $53 \%$ reduction in the pathogen incidence, respectively, in relation to the control.

Another finding was that the 100 and $150 \%$ concentrations of the biofungicide differed statistically from the 50\% concentration and the control, when the root protrusion variable was observed. The highest percentage was evidenced with the 100 and $150 \%$ concentrations, respectively 20 and $20.8 \%$ higher when compared to the $50 \%$ concentration, and 48.8 and $49.4 \%$, respectively, when compared to the control.

The results of the seedling damping off variable showed that the 100 and $150 \%$ concentrations of the biofungicide differed statistically from the $50 \%$ concentration and the control. Lower percentage of seedling damping off was found with the 100 and $150 \%$ concentrations, respectively 36.1 and $55.5 \%$ lower when compared to the $50 \%$ concentration, and 50 and $65 \%$, respectively, in relation to control.

In the tomato seedling test, all concentrations of biofungicide reduced the pathogen incidence, in the three evaluations (Table 3). A linear effect was observed in AUIPC, indicating a reduction in the pathogen incidence with the increase in the biofungicide concentration (Fig. 1).

According to BORTOLIN et al. (2019), seed treatment with $T$. harzianum isolates or their application to the soil promotes benefits to the germination and initial growth of plants. Based on these results, Trichoderma spp.-based products are proposed as an ecological alternative to the use of chemical products in agriculture (TRIANA et al., 2017).

CADORE et al. (2016) reported that plants with the root system colonized by Trichoderma spp. strains tend to show better development and are less susceptible to some infections than those that are not colonized. For those authors, the plant root system colonization by the fungus has a direct relation to the crop yield and its resistance to abiotic stresses. However, 
Table 2. Mean values of the pathogen incidence in tomato seeds, root protrusion and seedling damping off, after 7 days of the pathogen inoculation, submitted to the seed treatment with different concentrations of the biofungicide Trichodermil 1306.

\begin{tabular}{lccc} 
Treatments & Pathogen incidence (\%) & Root protrusion (\%) & Seedling damping off (\%) \\
\hline Control & $85 \pm 3.62 \mathrm{c}$ & $46 \pm 1.89 \mathrm{c}$ & $46 \pm 1.89 \mathrm{c}$ \\
\hline Trichodermil 50\% & $42 \pm 2.21 \mathrm{~b}$ & $72 \pm 0.00 \mathrm{~b}$ & $36 \pm 3.85 \mathrm{~b}$ \\
\hline Trichodermil 100\% & $40 \pm 1.48 \mathrm{~b}$ & $90 \pm 1.48 \mathrm{a}$ & $23 \pm 2.09 \mathrm{a}$ \\
\hline Trichodermil 150\% & $19 \pm 2.09 \mathrm{a}$ & $91 \pm 0.94 \mathrm{a}$ & $16 \pm 0.00 \mathrm{a}$ \\
\hline C.V. (\%) & 16.64 & 3.00 & 12.71 \\
\hline
\end{tabular}

*Means \pm EPM followed by the same letter in the column did not differ one from another in the Tukey's test at $5 \%$ probability.

Table 3. Mean values of fusarium wilt incidence in tomato seedlings, submitted to the seed treatment with different concentrations of the biofungicide Trichodermil 1306, for 30 days, in three evaluations.

\begin{tabular}{lccc} 
Treatments & $\mathbf{1}^{\text {st }}$ Evaluation & $2^{\text {nd }}$ Evaluation & $3^{\text {rd }}$ Evaluation \\
\hline Control & $5.6 \pm 1.16 \mathrm{~b}$ & $9.0 \pm 0.84 \mathrm{~b}$ & $9.0 \pm 0.84 \mathrm{~b}$ \\
\hline Trichodermil 50\% & $1.2 \pm 1.28 \mathrm{a}$ & $7.4 \pm 0.74 \mathrm{a}$ & $7.4 \pm 0.74 \mathrm{a}$ \\
\hline Trichodermil 100\% & $1.0 \pm 0.00 \mathrm{a}$ & $7.4 \pm 0.74 \mathrm{a}$ & $7.4 \pm 0.74 \mathrm{a}$ \\
\hline Trichodermil 150\% & $0.6 \pm 1.16 \mathrm{a}$ & $6.6 \pm 0.74 \mathrm{a}$ & $6.6 \pm 0.74 \mathrm{a}$ \\
\hline C.V (\%) & 43.25 & 7.88 & 7.88 \\
\hline
\end{tabular}

*Means \pm EPM followed by the same letter in the column did not differ one from another in the Tukey's test at $5 \%$ probability.

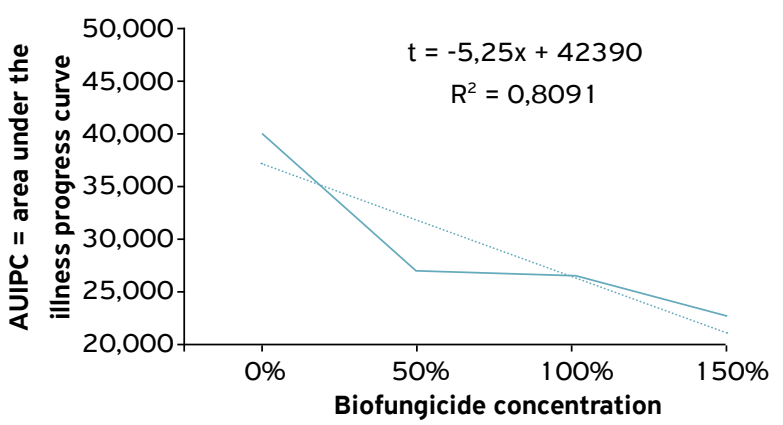

Figure 1. Incidence of $F$. oxysporum f. sp. lycopersici in tomato seedlings, as a function of different concentrations of the biological fungicide Trichodermil 1306.

some contradictory results were reported in the literature, in which Trichoderma spp. do not interfere in the crop growth (MACHADO et al., 2015).

The use of formulas containing Trichoderma spp. has been widely investigated by the scientific community. The researchers' interest is due to the multiple benefits that Trichoderma spp. promote to plants as inducers of resistance and promoters of vegetable growth; also, for its action in parasitism, antibiosis and competition with other fungi (CADORE et al., 2018).

In addition to their action in biocontrol, Trichoderma spp. might act as germination, emergence and vegetable growth stimulators (JUNGES et al., 2014). Such stimulus seems to be related to the production of vegetable phytohormones and the solubilization of mineral nutrients in the root zone such as phosphates and micronutrients (CADORE et al., 2018; LI et al., 2015).

The test results reported above indicate that the Trichodermil 1306 biofungicide can be used as an alternative treatment to tomato seeds, since it prevents the pathogen from influencing root protrusion and damping off symptoms from affecting the plantlets in addition to inhibiting the F. oxysporum f. sp. lycopersici growth.

\section{CONCLUSIONS}

The results of this study indicate that the $100 \%$ concentration of Trichodermil 1306 as the most efficient for treating tomato seeds. Although this concentration did not differ from the lowest dosage used (50\%) in the antagonism, mycoparasitism and $F$. oxysporum $\mathrm{f}$. sp. lycopersici incidence tests in tomato seedlings, were justified by the fact that the lowest concentration resulted in $18 \%$ less root protrusion than that observed with $100 \%$ concentration.

The in vitro antagonistic and mycoparasitory action of the biological fungicide tested in this study indicates its potential use in the control of fusarium wilt in tomato crops.

The biological fungicide action was efficient in the treatment of tomato seeds, suggesting a potential alternative to the use of chemical fungicides in this crop. 
ACKNOWLEDGEMENTS: Not applicable.

FUNDING: Universidade Federal da Fronteira Sul (Financial Support to Graduate Program Research/PES 2019-0597 459/2019)

CONFLICTS OF INTEREST: All authors declare that they have no conflict of interest.

ETHICAL APPROVAL: Not applicable.

AVAILABILITY OF DATA AND MATERIAL: The datasets generated and/or analyzed during the current study are available from the corresponding author on reasonable request.

AUTHORS' CONTRIBUTIONS: Conceptualization: Portolan, I.B.; Pietrobelli, S.R.; Fernandes, A.P.; Moura, G.S.; Bonome, L.T.S.; Franzener, G. Data curation: Portolan, I.B.; Pietrobelli, S.R. Funding acquisition: Bonome, L.T.S.; Franzener, G. Investigation: Portolan, I.B.; Pietrobelli, S.R. Methodology: Portolan, I.B.; Pietrobelli, S.R.; Fernandes, A.P.; Moura, G.S.; Bonome, L.T.S.; Franzener, G. Project administration: Fernandes, A.P.; Bonome, L.T.S.; Franzener, G. Supervision: Fernandes, A.P; Bonome, L.T.S.; Franzener, G. Writing — original draft: Portolan, I.B.; Pietrobelli, S.R.; Writing — review and editing: Portolan, I.B.; Pietrobelli, S.R.; Bonome, L.T.S.

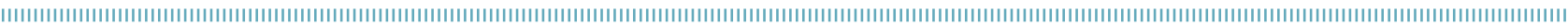
REFERENCES

BELL, D.K.; WELLS, H.D.; MARKHAM, C.R. In vitro antagonism of Trichoderma species against six fungal plant pathogens. Phytopathology, Athens, v.72, n.4, p.379-382, 1982. https:// doi.org/10.1094/Phyto-72-379

BORTOLIN, G.S.; WIETHAN, M.M.S.; VEY, R.T.; OLIVEIRA, J.C.P.; KÖPP, M.M.; SILVA, A.C.F. Trichoderma na promoção do desenvolvimento de plantas de Paspalum regnellii Mez. Revista de Ciências Agrárias, Lisboa, v.42, n.1, p.135-145, 2019. https://doi.org/10.19084/ RCA 18114

BRITO, J.P.C.; RAMADA, M.H.S.; MAGALHAẼS, M.T.Q.; SILVA, L.P.; ULHOA, C.J. Peptaibols from Trichoderma asperellum TR356 strain isolated from Brazilian soil. Springer Plus, Heidelberg, v.3, p.600, 2014. https://doi.org/10.1186/2193-1801-3-600

CADORE, L.S.; SILVA, N.G.; VEY, R.T.; SILVA, A.C.F. Inoculação de sementes com Trichoderma harzianum e Azospirillum brasiliense no desenvolvimento inicial de arroz. Enciclopédia Biosfera, Centro Científico Conhecer, Goiânia, v.13, n.24, p.1725-1731, 2016. https://doi.org/10.18677/EnciBio_2016B_158

CADORE, L.S.; VEY, R.T.; FREZINGHELI, J.C.F.; DOTTO, L.; ETHUR, L.Z. Avaliação do crescimento inicial da soja utilizando formulações de Trichoderma. Enciclopédia Biosfera, Centro Científico Conhecer, Goiânia, v.15, n.27, p.170-179, 2018. https://doi. org/10.18677/EnciBio_2018A16

CANTÚ, R.R.; REBELO, J.A.; MILANESI, P.M.; GOTO, R. Reação e resistência de porta-enxertos de tomateiro à murcha de fusário. Ciência Rural, Santa Maria, v.44, n.7, p. 1 155-1158, 2014. https://doi.org/10.1590/0103-8478cr20130843
CARRER FILHO, R.; DIANESE, É.C.; CUNHA, M.G. Aspectos moleculares da interação Fusarium oxysporum f. sp. lycopersici e o tomateiro. Revisão Anual de Patologia de Plantas, Goiânia, v.23, n. 1, p.110-127, 2015.

CARVALHO, D.D.C.; LOBO JUNIOR, M.; MARTINS, I.; INGLIS, P.W.; MELLO, S.C.M. Biological control of Fusarium oxysporumf. sp. Phaseoli by Trichoderma harzianum and its use for common bean seed treatment. Tropical Plant Pathology, Brasília, v.39, n.5, p.384-391, 2014a. https://doi.org/10.1590/S1982-56762014000500005

CARVALHO, C.R.F.; PONCIANO, N.J.; SOUZA, P.M.; SOUZA, C.L.M.; SOUSA, E.F. Viabilidade econômica e de risco da produção de tomate no município de Cambuci/RJ, Brasil. Ciência Rural, Santa Maria, v.44, n.12, p.2293-2299, 2014b. https://doi. org/10.1590/0103-8478cr20131570

CARVALHO, D.D.C.; MELLO, S.C.M.; MARTINS, I.; LOBO JUNIOR, M. Biological control of Fusarium wilt on common beans by in-furrow application of Trichoderma harzianum. Tropical Plant Pathology, Viçosa, v.40, n.6, p.375-381, 2015a. https://doi. org/10.1007/s40858-015-0057-1

CARVALHO, D.D.C.; GERALDINE, A.M.; LOBO JUNIOR, M.; MELLO, S.C.M. Biological control of white mold by Trichoderma harzianum in common bean under field conditions. Pesquisa Agropecuária Brasileira, Brasília, v.50, n.12, p.1220-1224,2015b. https:// doi.org/10.1590/SO100-204X2015001200012

FERRAZ, H.G.M.; RESENDE, R.S.; SILVEIRA, P.R.; ANDRADE, C.C.L.; MILAGRES, E.A.; OLIVEIRA, J.R.; RODRIGUES, F.Á. Rhizobacteria induces resistance against fusarium wilt of tomato by increasing the activity of defense enzymes. Bragantia, Campinas, v.73, n.3, p.274-283, 2014. https://doi.org/10.1590/1678-4499.0124 
FERREIRA, D.F. SISVAR: Sistema de análise de variância para dados balanceados, versão 5.0. Lavras: DEX/UFLA, 2007. CD-ROM. Software.

FERREIRA, R.B.; RODRIGUES, A.A.C.; MORAES, F.H.R.; SILVA, E.K.C.; NASCIMENTO, I.O. Resíduos orgânicos no controle de Fusarium oxysporum f. sp. passiflorae em maracujazeiro amarelo (Passiflora edulis f. flavicarpa). Acta Biologica Colombiana, Bogotá, v.20, n.3, p.111-120, 2015. https://doi.org/10.15446/abc. v20n3.44720

ISAIAS, C.O.; MARTINS, I.; SILVA, J.B.T.; SILVA, J.P.; MELLO, S.C.M. Ação antagônica e de metabólitos bioativos de Trichoderma spp. contra os patógenos Sclerotium rolfsii e Verticillium dahliae. Summa Phytopathologica, Botucatu, v.40, n. 1, p.34-41, 2014. https://doi.org/10.1590/S0100-54052014000100005

JUNGES, E.; BASTOS, B.O.; TOEBE, M.; MULLER, J.; PEDROSO, D.C.; MUNIZ, M.B. Water restriction and seed coating in the microbiolization of maize seeds with Trichoderma spp. Comunicata Scientiae, Bom Jesus, v.5, n.1, p. 18-25, 2014. Available from: https://comunicatascientiae.com.br/comunicata/article/ view/386. Access on: 12 Feb. 2019.

LI, R.-X.; CAI, F.; PANG, G.; SHEN, Q.-R.; LI, R.; CHEN, W. Solubilization of phosphate and micronutrients by Trichoderma harzianum and its relations with the promotion of tomato plant growth. PLOS ONE, San Francisco, v. 10, n.6, p.e0130081, 2015. https://doi. org/10.1371/journal.pone.0130081

MACHADO, D.F.M.; TAVARES, A.P.; LOPES, S.J.; SILVA, A.C.F. Trichoderma spp. na emergência e crescimento de mudas de cambará (Gochnatia polymorpha (Less.) Cabrera). Revista Árvore, Viçosa, v.39, n.1, p.167-176, 2015. https://doi. org/10.1590/0100-67622015000100016

MARTÍNEZ, R.H.; BENIITEZ, A.L.; ESCALANTE, F.B.; VELÁZQUEZ, J.E.; ASPEYTIA, D.S.; MENDONZA, I.E.M.; OCHOA, L.A.L. Razas de Fusarium oxysporum $\mathrm{f}$. sp. Lycopersici em prédios tomateiros en San Luis Potosí. Revista Mexicana de Ciencias Agrícolas, Mexico City, v.5, n.7, p. 1 169-1 178,2014. https://doi.org/10.29312/ remexca.v5i7.838

MELO, T.A.; SERRA, I.M.R.S. Materiais vegetais aplicados ao manejo agroecológico de Meloidogyne incognita em tomateiro. Summa Phytopathologica, Botucatu, v.45, n. 1, p.97-103, 2019. https://doi.org/10.1590/0100-5405/187851
SILVA, G.B.P.; HECKLER, L.I.; SANTOS, R.F.; DURIGON, M.R.; BLUME, E. Identificação e utilização de Trichoderma spp. armazenados e nativos no biocontrole de Sclerotinia sclerotiorum. Revista Caatinga, Mossoró, v.28, n.4, p.33-42,2015. https://doi. org/10.1590/1983-21252015v28n404rc

SILVA, F.F.; CASTRO, E.M.; MOREIRA, S.I.; FERREIRA, T.C.; LIMA, A.E.; ALVES, E. Emergência e análise ultraestrutural de plântulas de soja inoculadas com Sclerotinia sclerotiorum sob efeito da aplicação de Trichoderma harzianum. Summa Phytopathologica, Botucatu, v.43, n.1, p.41-45, 2017. https:// doi.org/10.1590/0100-5405/2212

SOLINO, A.J.S.; OLIVEIRA, J.B.S.; SCHWAN-ESTRADA, K.R.F.; ALENCAR, M.S.R.; RIBEIRO, L.M. Potencial antagonista e controle in vitro de Alternaria solani por fungos sapróbios. Summa Phytopathologica, Botucatu, v.43, n.3, p.199-204, 2017. https:// doi.org/10.1590/0100-5405/2202

SOUZA, J.R.; REBOUÇAS, T.N.H; SILVA, J.P.; SANTANA, C.M.P.; FIGUEIREDO, R.M. Efeito de fungicida biológico e químico no controle da requeima e na qualidade de frutos do tomateiro. Enciclopédia Biosfera. Centro Científico Conhecer, Goiânia, v.10, n. 19, p.866-873, 2014. Available from: http://www.conhecer.org. br/enciclop/2014b/AGRARIAS/EFEITO\%2ODE\%2OFUNGICIDA. pdf. Access on: 10 Mar. 2019.

SOUZA, Â.R.L.; MACHADO, J.A.D.; DALCIN, D. Análise de estudos internacionais sobre os fatores que influenciam a decisão dos agricultores pela produção orgânica. Revista em Agronegócio e Meio Ambiente, Maringá, v.8, n.3, p.563-583,2015. https://doi. org/10.17765/2176-9168.2015v8n3p563-583

TRIANA, A.C.; GONZÁLEZ, D.R.; COCA, B.M.; HERNÁNDEZ, A.E.; RODRÍGUEZ, A.T. Evaluación de la actividad antifúngica de Trichoderma asperellum Samuels ante patógenos fúngicos que afectan al cultivo de la soya (Glycine max L.). Cultivos Tropicales, Habana, v.38, n.4, p.15-21, 2017. Available from: http://scielo.sld.cu/scielo.php?script=sci_arttext\&pi $\mathrm{d}=$ SO258-59362017000400006. Access on: 25 Feb. 2019.

ZHANG, F; GE, H.; ZHANG, F.; GUO, N.; WANG, Y.; CHEN, L.; JI, $\mathrm{X}$.; LI, C. Biocontrol potential of Trichoderma harzianum isolate T-aloe against Sclerotinia sclerotiorum in soybean. Plant Physiology and Biochemistry, Paris, v.100, p.64-74, 2016. https://doi. org/10.1016/j.plaphy.2015.12.017 